\title{
PENGARUH PENGUNGKAPAN COORPORATE SOCIAL RESPONSIBILITY (CSR) TERHADAP PROFITABILITAS PERUSAHAAN PERTAMBANGAN YANG TERDAFTAR DI BURSA EFEK INDONESIA
}

\author{
Hendri Celvin \\ Romasi Lumban Gaol
}

\begin{abstract}
Abstrak
Penelitian ini bertujuan untuk mengetahui dan menganalisis pengaruh Pengungkapan Corporate Social Responsibility (CSR) Terhadap Profitabilitas perusahaan pertambangan yang terdaftar di Bursa Efek Indonesia. Populasi dalam penelitian ini adalah seluruh perusahaan pertambangan yang terdaftar di Bursa Efek Indonesia (BEI) selama periode 2011-2013. Teknik pengambilan sampel yang digunakan dalam penelitian ini adalah teknik purposive sampling. Jumlah sampel penelitian ini adalah sebanyak 20 perusahaan pertambangan yang telah memenuhi kriteria penentuan sampel. Data diperoleh dari website resmi Bursa Efek Indonesia tahun 2011 sampai dengan 2013. Teknik analisis data yang digunakan adalah regresi linier sederhana dan pengujian hipotesis menggunakan uji statistik t dengan tingkat signifikansi sebesar 5\%. Hasil uji statistik t menunjukkan bahwa Corporate Social Responsibility (CSR) tidak mempengaruhi profitabilitas yang diwakilkan oleh Net Profit Margin (NPM) dan Return On Asset (ROA). Adapun saran yang dapat peneliti berikan untuk perusahaan adalah agar tetap melakukan kegiatan CSR meskipun tidak mempengaruhi profitabilitas, karena investor cenderung berinvestasi pada perusahaan yang melaksanakan kegiatan CSR. Adapun saran untuk peneliti selanjutnya adalah agar mengganti variabel dependen lain yang dapat dipengaruhi oleh CSR.
\end{abstract}

Kata kunci : Corporate Social Responsibility (CSR), Net Profit Margin (NPM), dan Return On Asset (ROA)

\section{PENDAHULUAN}

Corporate social responsibility (CSR) atau juga dikenal dengan triple bottom line (Economic, Sosial, and Environmental) telah ada sejak abad ke-19, yang dimulai dengan revolusi industri. Tanggungjawab sosial perusahaan (corporate social responsibility) kemudian semakin mendapatkan perhatian oleh kalangan dunia usaha. Di Indonesia sejak era reformasi bergulir, masyarakat semakin kritis dan mampu melakukan kontrol sosial terhadap dunia usaha. Perubahan pada tingkat kesadaran masyarakat tersebut memunculkan kesadararan baru tentang pentingnya melaksanakan corporate social responsibility (CSR) (Daniri, 2007). Menurut Utama (2007) perkembangan CSR juga terkait dengan semakin parahnya kerusakan lingkungan yang terjadi di Indonesia maupun dunia, 
mulai dari penggundulan hutan, polusi udara dan air, hingga perubahan iklim.

Sejalan dengan perkembangan tersebut, Undang-Undang RI No. 40 tahun 2007 tentang Perseroan Terbatas mewajibkan perseroan yang bidang usahanya di bidang atau terkait dengan bidang sumber daya alam untuk melaksanakan tanggung jawab sosial dan lingkungan. Selain itu, berdasarkan Undang-Undang Penanaman Modal No. 25 tahun 2007 pasal 15 dan 34 disebutkan bahwa perusahaan yang tidak melaksanakan CSR akan dikenakan sanksi administratif berupa peringatan tertulis, pembatalan kegiatan usaha, pembekuan kegiatan usaha, dan yang terakhir adalah pencabutaan izin kegiatan.

Adanya pengungkapan tanggungjawab sosial ini oleh perusahaanperusahaan diharapkan mampu memberikan kontribusi yang baik bagi berbagai pihak. Baik bagi masyarakat sebagai pihak yang menjadi objek pemberlakuan CSR ini, juga bagi perusahaan yang tentunya tetap membutuhkan adanya keuntungan dari setiap tindakan dan kebijakan yang diambilnya. Dana yang digunakan untuk CSR ini di ungkapkan dalam laporan tahunan yang diterbitkan oleh perusahaan.

Dana yang telah dialokasikan untuk CSR tersebut tentunya akan berpengaruh terhadap perusahaan, khususnya terhadap profitabilitas perusahaan. Profitabilitas merupakan kemampuan suatu perusahaan untuk menghasilkan laba dalam periode tertentu. Rasio profitabilitas mengindikasikan seberapa efektif pengelolaan perusahaan secara keseluruhan dan mengukur seberapa besar kemampuan perusahaan memperoleh laba baik dalam hal yang berhubungan dengan penjualan, aset, maupun laba bagi modal sendiri. Profitabilitas dapat diukur dengan menggunakan rasio-rasio profitabilitas, yaitu Return On Asset (ROA), Return On Equity (ROE), Net Profit Margin (NPM), Operating Profit Margin (OPM), GrossProfit Margin (GPM), Cash Flow Margin (CFM), Cash Return on Asset, serta Basic Earning Power (BEP) .

Dengan mengungkapkan CSR, akan terbangun citra perusahaan yang baik di mata masyarakat. Masyarakat akan mempunyai pandangan yang bagus karena perusahaan telah memperlihatkan kepedulian terhadap masyarakat dan lingkungannya, sehingga masyarakat tidak keberatan menggunakan produk dari perusahaan tersebut. Semakin banyak masyarakat menggunakan produk, maka akan meningkatkan penjualan perusahaan yang tentunya juga akan menyababkan profitabilitas pun ikut meningkat. 
Namun demikian pengungkapan CSR oleh perusahaan belum sepenuhnya menjamin profitabilitas perusahaan naik. Sebagai contoh berikut merupakan data pengungkapan Corporate Social Responsibility (CSR), penjualan, laba(rugi), serta Return On Asset (ROA) dari PT Bayan Resources Tbk untuk tahun 2011-2013 :

Tabel 1

Data CSR, Penjualan, Laba(Rugi), Serta ROA PT Bayan Resources Tbk.

Tahun 2011-2013

\begin{tabular}{|c|c|c|c|c|}
\hline Tahun & $\begin{array}{c}\text { Item } \\
\text { CSR }\end{array}$ & Penjualan & Laba(Rugi) & ROA \\
\hline 2011 & 19 & Rp. 13.235.900.000.000 & Rp. 1.831.700.000.000 & 0,127 \\
\hline 2012 & 24 & USD 1.422.880.281 & USD 54.946.917 & 0,029 \\
\hline 2013 & 26 & USD 1.147.467.928 & (USD 55.216.028) & $-0,035$ \\
\hline
\end{tabular}

Sumber : www.idx.co.id (data diolah)

PT Bayan Resources Tbk ini merupakan salah satu sampel dalam penelitian ini. Pada Tahun 2012 PT Bayan Resources Tbk mengalami penurunan laba. Bahkan pada tahun 2013, PT Bayan Resources Tbk mengalami kerugian. Padahal pengungkapan CSR dalam laporan keuangan mereka selalu meningkat pada tahun 2012-2013. Selain itu turunnya laba pada tahun 2012 serta kerugian pada tahun 2013 juga membuat profitabilitas PT Bayan Resources Tbk mengalami penurunan.

Dari tabel diatas terlihat bahwa pendapatan dan tingkat ROA PT Bayan Resources Tbk. turun pada tahun 2012 dan 2013. Padahal pada tahun 2012 dan 2013 PT Bayan Resources Tbk melakukan banyak Corporate Social Responsibility (CSR) yang dapat dilihat melalui laporan tahunannya dibandingkan dengan tahun 2011. Melalui hal diatas terlihat bahwa CSR tidak selalu berpengaruh positif atau sama sekali tidak berpengaruh terhadap penjualan dan profitabilitas perusahaan.

Hal diatas sejalan dengan hasil beberapa penelitian tentang CSR yang tidak menunjukkan hasil yang konsisten. Terdapat hasil yang berbeda-beda diantaranya, Tsoutsoura (2004) menyatakan bahwa ada pengaruh positif antara pengungkapan CSR terhadap profitabilitas yang diukur dengan ukuran kinerja keungan return on investment (ROI) dan 
return on equity (ROE). Lalu penelitian Novi Resturiyani (2012) menyatakan bahwa tingkat pengungkapan CSR dalam laporan tahunan perusahaan berpengaruh positif terhadap variabel ROI. Hasil berbeda ditemukan dalam penelitian Nelling dan Webb (2006) yang menemukan bahwa hubungan pengungkapan CSR dengan kinerja keuangan adalah negatif signifikan. Sementara itu Penelitian Fauzi (2004) menunjukkan pengungkapan tanggung jawab sosial berpengaruh negatif terhadap kinerja keungan (profitabilitas). Januarti dan Apriyanti (2005) menunjukkan bahwa biaya kesejahteraan karyawan tidak berpengaruh terhadap return on assets, biaya untuk komunitas (sumbangan) tidak berpengaruh terhadap return on assets, dan secara simultan biaya kesejahteraan karyawan (ension) dan biaya untuk komunitas (sumbangan) tidak berpengaruh terhadap total assets turnover.

Berdasarkan fenomena yang terjadi pada tabel 1.1 bahwa Peningkatan CSR tidak memberikan pengaruh terhadap penjualan dan profitabilitas perusahaan. Serta melihat hasil beberapa penelitian yang berbeda-beda yang dijelaskan diatas, peneliti tertarik melakukan penelitian tentang pengaruh CSR terhadap profitabilitas.

Penelitian ini melakukan studi kasus pada perusahaan pertambangan yang terdaftar di Bursa Efek Indonesia selama periode 2011-2013. Perusahaan pertambangan dipilih oleh peneliti karena merupakan salah satu jenis usaha yang menyebabkan kerusakan lingkungan, sehingga tentu perusahaan pertambangan perlu melakukan pengungkapan CSR yang luas di dalam laporan tahunannya.

\section{TINJAUAN PUSTAKA}

\section{Corporate Sosial Responsibility (CSR)}

Corporate Sosial Responsibility (CSR) atau tanggungjawab sosial perusahaan merupakan suatu upaya tanggungjawab perusahaan atau organisasi atas dampak yang ditimbulkan dari keputusan dan aktivitas yang telah diambil dan dilakukan oleh organisasi tersebut, dimana dampak itu pastinya akan dirasakan oleh pihak-pihak terkait termasuk masyarakat dan lingkungan.

Menurut Branco dan Rodrigues dalam Mursitama dkk (2011:2731), membagi dua manfaat CSR bila dikaitkan dengan keunggulan kompetitif (competitive advantage) dari sebuah perusahaan, yaitu dari sisi internal maupun eksternal.

1. Manfaat Internal CSR, yaitu:

a. Pengembangan aktivitas yang berkaitan dengan sumber daya manusia. 
b. Adanya pencegahan polusi dan reorganisasi pengelolaan proses produksi dan aliran bahan baku, serta hubungan dengan supplier yang berjalan dengan baik.

c. Menciptakan budaya perusahaan, kapasitas sumber daya manusia, dan organisasi yang baik.

d. Kinerja keuangan. Dengan dilakukannya CSR, kinerja keuangan perusahaan menjadi lebih baik.

2. Manfaat eksternal CSR, yaitu:

a. Penerapan CSR akan meningkatkan reputasi perusahaan sebagai badan yang mengemban dengan baik pertanggungjawaban secara sosial.

b. CSR merupakan satu bentuk diferensiasi produk yang baik.

c. Melaksanakan CSR dan membuka kegiatan CSR itu secara publik merupakan instrumen untuk komunikasi yang baik dengan khayalak.

d. Kontribusi CSR terhadap kinerja perusahaan pun dapat terwujud paling tidak dalam dua bentuk. Pertama, dampak positif yang timbul sebagai insentif (rewards) atas tingkah laku positif dari perusahaan. Kedua, kemampuan perusahaan untuk mencegah munculnya konsekuensi dari tindakan yang buruk atau dikenal sebagai "jaring pengaman" atau safety nets bagi perusahaan.

Indikator-indikator untuk mengukur pengungkapan CSR menurut Hackston dan Milne (1999) dalam Eddy Rismanda Sembiring (2005) adalah sebagai berikut:

1) Lingkungan

1. Pengendalian polusi kegiatan operasi, pengeluaran riset dan pengembangan untuk mengurangi polusi.

2. Operasi perusahaan tidak mengakibatkan polusi atau memenuhi ketentuan hukum dan peraturan polusi.

3. Pernyataan yang menunjukkan bahwa polusi operasi telah atau akan dikurangi.

4. Pencegahan atau perbaikan kerusakan lingkungan akibat pengelolaan sumber alam, misalnya reklamasi daratan atau reboisasi.

5. Konservasi sumber alam, misalnya mendaur ulang kaca, besi, minyak, air dan kertas.

6. Penggunaan material daur ulang

7. Menerima penghargaan berkaitan dengan program lingkungan yang dibuat perusahaan.

8. Merancang fasilitas yang harmonis dengan lingkungan. 
9. Kontribusi dalam seni yang bertujuan untuk memperindah lingkungan.

10. Kontribusi dalam pemugaran bangunan sejarah.

11. Pengelolaan limbah.

12. Riset mengenai pengelolaan limbah.

13. Mempelajari dampak lingkungan untuk memonitor dampak lingkungan perusahaan.

14. Perlindungan lingkungan hidup.

2) Energi

1. Menggunakan energi secara lebih efisien dalam kegiatan operasi.

2. Memanfaatkan barang bekas untuk memproduksi energi.

3. Penghematan energi sebagai hasil produk daur ulang.

4. Membahas upaya perusahaan dalam mengurangi konsumsi energi.

5. Peningkatan efisiensi energi dan produk.

6. Riset yang mengarah pada peningkatan efisiensi energi dari produk.

7. Mengungkapkan kebijakan energi perusahaan.

3) Kesehatan dan Keselamatan Kerja

1. Mengurangi polusi, iritasi, atau resiko dalam lingkungan kerja.

2. Mempromosikan keselamatan tenaga kerja dan kesehatan fisik atau mental.

3. Mengungkapkan statistik kecelakaan kerja.

4. Mentaati peraturan standar kesehatan dengan keselamatan kerja.

5. Menerima penghargaan berkaitan dengan keselamatan kerja.

6. Menetapkan suatu komite keselamatan kerja.

7. Melaksanakan riset untuk meningkatkan keselamatan kerja.

8. Mengungkapkan pelayanan kesehatan tenaga kerja.

4) Lain-lain Tentang Tenaga Kerja

1. Perekrutan atau memanfaatkan tenaga kerja wanita / orang cacat.

2. Mengungkapkan persentase/jumlah tenaga kerja wanita / orang cacat dalam tingkat managerial.

3. Mengungkapkan tujuan penggunaan tenaga kerja wanita / orang cacat dalam pekerjaan.

4. Program untuk kemajuan tenaga kerja wanita/orang cacat.

5. Pelatihan tenaga kerja melalui program tertentu di tempat kerja.

6. Memberikan bantuan keuangan pada tenaga kerja dalam bidang pendidikan.

7. Mendirikan suatu pusat pelatihan tenaga kerja. 
8. Mengungkapkan bantuan atau bimbingan untuk tenaga kerja yang dalam proses mengundurkan diri atau yang telah membuat kesalahan.

9. Mengungkapkan perencanaan kepemilikan rumah karyawan.

10. Mengungkapkan fasilitas untuk aktivitas rekreasi.

11. Pengungkapan persentase gaji untuk pensiun.

12. Mengungkapkan kebijakan penggajian dalam perusahaan.

13. Mengungkapkan jumlah tenaga kerja dalam perusahaan.

14. Mengungkapkan tingkatan manajerial yang ada.

15. Mengungkapkan disposisi staff dimana staff ditempatkan.

16. Mengungkapkan jumlah staff, masa kerja dan kelompok usia mereka.

17. Mengungkapkan statistik tenaga kerja, misalnya penjualan per tenaga kerja.

18. Mengungkapkan kualifikasi tenaga kerja yang direkrut.

19. Mengungkapkan rencana kepemilikan saham oleh tenaga kerja.

20. Mengungkapkan rencana pembagian keuntungan lain.

21. Mengungkapkan informasi hubungan manajemen dengan tenaga kerja dalam meningkatkan keputusan dan motivasi kerja.

22. Mengungkapkan informasi stabilitas pekerjaan tenaga kerja dan masa depan perusahaan.

23. Membuat laporan tenaga kerja yang terpisah.

24. Melaporkan hubungan perusahaan dengan serikat buruh.

25. Melaporkan gangguan dan aksitenaga kerja.

26. Mengungkapkan informasi bagaimana aksi tenaga kerja dinegosiasikan.

27. Peningkatan kondisi kerja secara umum.

28. Informasi reorganisasi perusahaan yang mempengaruhi tenaga kerja.

29. Informasi dan statistik perputaran tenaga kerja.

5) Produk

1. Pengungkafan informasi pengembangan produk perusahaan, termasuk pengemasan.

2. Gambaran pengeluaran riset dan pengembangan produk.

3. Pengungkapan informasi proyek riset perusahaan untuk memperbaiki produk.

4. Pengungkapan bahwa produk memenuhi standar keselamatan.

5. Membuat produk lebih aman untuk konsumen.

6. Melaksanakan riset atas tingkat keselamatan produk perusahaan. 
7. Pengungkapan peningkatan kebersihan/kesehatan dalam pengolahan dan penyiapan produk.

8. Pengungkapan informasi atas keselamatan produk perusahaan.

9. Pengungkapan informasi mutu produk yang dicerminkan dalam penerimaan penghargaan

10. Informasi yang dapat diverifikasi bahwa mutu produk telah meningkat (misalnya, ISO 9000).

6) Keterlibatan Masyarakat

1. Sumbangan tunai, produk, pelayanan untuk mendukung aktivitas masyarakat, pendidikan, dan seni.

2. Tenaga kerja paruh waktu (part-time employment) dari mahasiswa/pelajar.

3. Sebagai sponsor untuk proyek kesehatan masyarakat.

4. Membantu riset media.

5. Sebagai sponsor untuk konferensi pendidikan, seminar ataupameran seni.

6. Membiayai program beasiswa.

7. Membuka fasilitas perusahaan untuk masyarakat.

8. Mensponsori kampanye nasional.

9. Mendukung pengembangan industri lokal.

7) Umum

1. Pengungkapan tujuan. Kebijakan perusahaan secara umum berkaitan dengan tanggung jawab sosial perusahaan kepada masyarakat.

2. Informasi hubungan dengan tanggung jawab sosial perusahaan selain yang disebut di atas.

\section{Profitabilitas}

Menurut Petronila dan Mukhlasin (2003) dalam Wahidahwati (2002), profitabilitas merupakan gambaran dari kinerja manajemen dalam mengelola perusahaan. Sedangkan Munawir (2001), mendefinisikan profitabilitas sebagai keefektifan operasi serta derajat keuangan suatu perusahaan. Menurut Septiana (2012) profitabilitas perusahaan merupakan kemampuan perusahaan dalam menghasilkan laba bersih dari aktivitas yang dilakukan pada periode akuntansi.

Ukuran ratio profitabilitas antara lain

a. Marjin Laba Kotor / Gross Profit Margin (GPM).

Rasio ini digunakan untuk mengukur persentase laba kotor dari setiap penjualan yang dilakukan oleh perusahaan. 
b. Marjin Laba Bersih / Net Profit Margin (NPM).

Marjin laba bersih atas penjualan digunakan untuk mengukur persentase laba bersih dari setiap penjualan yang dilakukan oleh perusahaan.

c. Tingkat Pengembalian atas Aset/ Return on Assets (ROA).

Return On Asset ini mengukur efisiensi dari penggunaan sumber daya (aset) untuk menghasilkan laba bersih bagi perusahaan. ROA menunjukkan kemampuan perusahaan menghasilkan laba dari aset yang dipergunakan.

d. Tingkat Pengembalian atas Ekuitas / Return On Equity (ROE).

Rasio ini menunjukkan tingkat pengembalian yang diberikan oleh perusahaan untuk setiap rupiah modal dari pemilik, yang diperoleh dengan cara membagi laba bersih dengan total ekuitas.

3 Net Profit Margin (NPM) Dan Return On Asset (ROA) Sebagai Indikator Profitabilitas

a. Net Profit Margin (NPM)

NPM ditentukakan dengan rumus berikut:

$$
\mathbf{N P M}=\frac{\text { Laba Bersih }}{\text { Penjualan }}
$$

\section{b. Return On Asset (ROA)}

Rumus yang dapat digunakan untuk menghitung Return on Asset (ROA) adalah sebagai berikut:

$$
\text { ROA }=\frac{\text { Laba Bersih Setelah Pajak }}{\text { Total Aktiva }}
$$

\section{Hubungan CSR dengan Profitabilitas}

Herremans et al dalam Iryanie (2009) mengemukakan beberapa pokok pikiran mengenai hubungan antara tanggungjawab sosial perusahaan dan kinerja ekonomi, antara lain:

a. Pokok pikiran yang menggambarkan kebijakan konvensional; berpendapat bahwa terdapat biaya tambahan yang signifikan dan akan menghilangkan peluang perolehan laba untuk melaksanakan tanggung jawab sosial, sehingga akan menurunkan profitabilitas. 
b. Biaya tambahan khusus untuk melaksanakan tanggung jawab sosial akan menghasilkan dampak netral terhadap profitabilitas, hal ini karena tambahan biaya yang dikeluarkan tertutupi oleh keuntungan efesiensi yang ditimbulkan oleh pengeluaran biaya tersebut.

c. Pokok pikiran yang memprediksikan bahwa tanggung jawab sosial perusahaan berdampak positif terhadap profitabilitas.

Sementara itu Fombrun et al (2000) dalam Dewa (2010) menyatakan bahwa tanggung jawab sosial perusahaan dapat meningkatkan reputasi perusahaan terhadap konsumen sehingga meningkatkan profitabilitas perusahaan.

\section{Kerangka Pemikiran}

Meningkatnya NPM dan ROA berarti biaya yang dikeluarkan untuk program CSR oleh perusahaan digunakan dengan efisien untuk menghasilkan tingkat profitabilitas yang tinggi. Peningkatan profitabilitas perusahaan kemungkinan juga dipengaruh oleh pengungkapan programprogram corporate social responsibility (CSR) yang dilakukan oleh perusahaan. Jika dikelola dengan baik program CSR atau tanggung jawab sosial perusahaan ini dapat menghasilkan manfaat yang signifikan dalam bentuk reputasi perusahaan (Gilangsantika, 2009:44-45) dan akan menguntungkan eksistensi perusahaan dalam waktu yang panjang. Reputasi perusahaan merupakan penilaian atau tanggapan masyarakat (konsumen) terhadap pembentukan citra perusahaan yang berdampak positif bagi perusahaan.

Berdasarkan uraian di atas, dapat diduga bahwa dengan melaksanakan Corporate Social Responsibility (CSR) maka citra perusahaan akan meningkat. Perusahaan yang memiliki reputasi baik tentu mengundang banyak pihak untuk membeli produk yang dihasilkannya. Ini berarti dalam jangka waktu tertentu akan menyebabkan penjualan meningkat pula. Para investor pun akan menilai perusahaan dari laporan keuangan perusahaan tersebut, dan akan menanamkan modalnya semakin banyak. Hal ini diharapkan mampu mempengaruhi profitabilitas perusahaan dalam jangka panjang, sehingga perusahaan akan mengalami kemajuan. Untuk penelitian ini digunakan kerangka penelitian, sebagai berikut: 


\section{Gambar 2.1 Kerangka Penelitian}

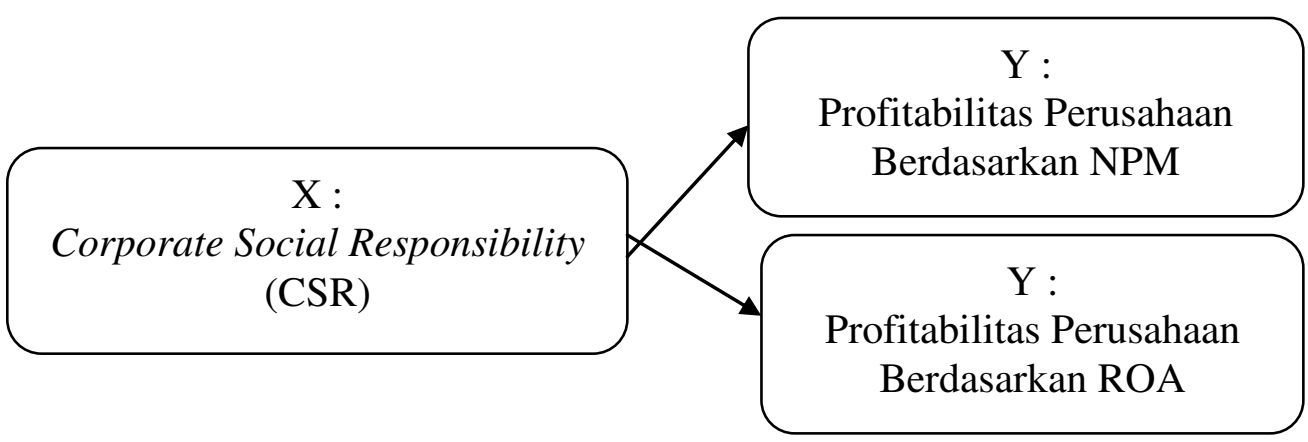

\section{Hipotesis}

Berdasarkan kerangka penelitian tersebut diatas, maka peneliti mengemukakan hipotesis dalam penelitian ini yaitu :

H1 : Terdapat Pengaruh pengungkapan Corporate Social Responsibility (CSR) terhadap Net Profit Margin (NPM) pada perusahaan pertambangan yang tercatat di Bursa Efek Indonesia (BEI).

H2 : Terdapat Pengaruh pengungkapan Corporate Social Responsibility (CSR) terhadap Return On Asset (ROA) pada perusahaan pertambangan yang tercatat di Bursa Efek Indonesia (BEI).

\section{METODE PENELITIAN}

\section{a. Populasi dan Sampel}

Adapun objek yang dijadikan populasi dalam penelitian ini adalah seluruh perusahaan pertambangan yang terdaftar di Bursa Efek Indonesia selama 3 tahun, yaitu periode 2011-2013. Populasi penelitian terdiri dari 27 perusahaan pertambangan yang terdaftar selama 3 tahun, yaitu periode 2011-2013.

Pengambilan sampel dalam penelitian ini dilakukan dengan menggunakan teknik non random sampling, yaitu cara pengambilan sampel yang tidak semua anggota populasi diberi kesempatan untuk dipilih menjadi sampel. Salah satu teknik pengambilan sampel yang termasuk dalam teknik non random sampling adalah metode purposive sampling.

Tabel 3.1

\section{Penentuan Sampel Penelitian}

\begin{tabular}{|c|c|c|}
\hline No. & Kriteria Pemilihan Sampel & Jumlah \\
\hline 1 & Seluruh perusahaan pertambangan yang terdaftar di Bursa & 27 \\
\hline
\end{tabular}




\begin{tabular}{|c|l|c|}
\hline & $\begin{array}{l}\text { Efek Indonesia (BEI) selama 3 tahun berturut-turut } \\
\text { (Periode 2011-2013 }\end{array}$ & (6) \\
\hline 2 & $\begin{array}{l}\text { Perusahaan pertambangan yang terdaftar di Bursa Efek } \\
\text { Indonesia (BEI) selama 3 tahun (Periode 2011-2013 } \\
\text { tetapi tidak menyampaikan laporan tahunan selama 3 } \\
\text { tahun berturut-turut (periode 2011-2013) }\end{array}$ & $\begin{array}{l}\text { Perusahaan pertambangan yang tidak mengungkapkan } \\
\text { informasi Corporate Social Responsibility (CSR) dalam } \\
\text { laporan tahunannya }\end{array}$ \\
\hline 4 & $\begin{array}{l}\text { Perusahaan pertambangan yang dijadikan sampel } \\
\text { penelitian }\end{array}$ & 20 \\
\hline 5 & $\begin{array}{l}\text { Total sampel dalam penelitian ini (perusahaan } \\
\text { pertambangan yang dijadikan sampel x jumlah tahun data } \\
\text { penelitian) } \\
\text { Total Sampel =20 perusahaan x 3 tahun }\end{array}$ & 60 \\
\hline
\end{tabular}

Sumber : Olah data peneliti

\subsection{Operasionalisasi Variabel}

\subsubsection{Corporate Social Responsibility (CSR)}

Informasi mengenai Corporate Social Responsibility Disclosure Index (CSDI) yang akan digunakan dalam penelitian ini adalah berdasarkan indikator yang telah disebutkan pada Bab II menurut Hackston dan Milne (1999) dalam Eddy Rismanda Sembiring (2005) yang terdiri dari 79 item pengungkapan CSR. Informasi mengenai pengungkapan CSR ini didapat melalui laporan tahunan perusahaan.

Perhitungan indeks CSDI dilakukan dengan menggunakan pendekatan dikotomi yaitu setiap item CSR dalam instrumen penelitian yang diungkapkan oleh perusahaan diberikan nilai 1 dan nilai 0 jika tidak diungkapkan (Hanifa dalam Indrawan 2011:43). Rumus perhitungan CSDI adalah sebagai berikut:

Dimana :

$$
\mathrm{CSDI}_{\mathrm{j}}=\frac{X_{i j}}{n_{j}}
$$

CSDIj : Corporate Social Disclosure Index perusahaan $\mathrm{j}$

$\mathrm{X}_{\mathrm{ij}} \quad: 1=$ jika item $\mathrm{i}$ diungkapkan; $0=$ jika item i tidak diungkapkan

$n_{j} \quad$ : Jumlah item CSR yang mungkin dipenuhi oleh perusahaan $\mathrm{j}, \mathrm{n}_{\mathrm{j}}=$ 79

Dengan demikian, $0 \leq \mathrm{CSDI}_{\mathrm{j}} \leq 1$ 


\subsubsection{Pengukuran Profitabilitas}

Variabel dependen atau variabel terikat dalam penelitian ini adalah profitabilitas perusahaan yang diwakilkan oleh Net Profit Margin (NPM) dan Return On Asset (ROA)

\section{c. Net Profit Margin (NPM)}

Menurut Sartono (2001) rumus yang dapat digunakan untuk menghitung NPM adalah:

\section{d. Return On Asset (ROA)}

$$
\mathbf{N P M}=\frac{\text { Laba Bersih }}{\text { Penjualan }}
$$

Menurut Sartono (2001) rumus yang dapat digunakan untuk menghitung NPM adalah:

\section{Teknik Pengumpulan Data}

$$
\text { ROA }=\frac{\text { Laba Bersih Setelah Pajak }}{\text { Total Aktiva }}
$$

Teknik pengumpulan data yang dilakukan dalam penelitian ini adalah observasi dan studi dokumentasi terhadap laporan keuangan tahunan perusahaan. Observasi atau studi pustaka (literatur) melalui buku teks, literatur, artikel dalam jurnal, hasil penelitian terdahulu serta sumber data tertulis lainnya yang berhubungan dengan informasi yang dibutuhkan. Studi dokumentasi merupakan proses perolehan dokumen dengan mengumpulkan data berupa laporan keuangan tahunan (annual report) perusahaan pertambangan yang terdaftar di Bursa Efek Indonesia (BEI) selama 3 tahun, periode 2011-2013 yang diperoleh dari situs www.idx.co.id.

\section{Teknik Analisis Data}

\subsubsection{Uji Asumsi Klasik}

Uji asumsi klasik yang digunakan dalam penelitian ini adalah uji normalitas data, uji multikolonieritas, uji heteroskedatisitas, dan uji autokorelasi, karena data yang digunakan lebih dari satu tahun.

\subsubsection{Analisis Regresi Linear Sederhana}

a. Pengaruh CSR terhadap Net Profit Margin (NPM)

$$
\mathbf{Y}=\mathbf{a}+\mathbf{b X}+\mathrm{e}
$$


Dimana:

$\mathrm{Y}=$ Net Profit Margin (NPM)

$\mathrm{X}=$ Corporate Social Responsibility Disclosure Index perusahaan (CSDI)

$\mathrm{b}=$ Koefisien regresi untuk mengukur besarnya pengaruh $\mathrm{X}$ terhadap $\mathrm{Y}$

$\mathrm{a}=$ Konstanta

$\mathrm{e}=$ Epsilon atau variabel pengganggu

\section{b. Pengaruh CSR terhadap Return On Asset (ROA)

$$
\mathbf{Y}=\mathbf{a}+\mathbf{b X}+\mathrm{e}
$$

Dimana:

$\mathrm{Y}=$ Return On Asset (ROA)

$\mathrm{X}=$ Corporate Social Disclosure Index perusahaan (CSDI)

$\mathrm{b}=$ Koefisien regresi untuk mengukur besarnya pengaruh $\mathrm{X}$ terhadap $\mathrm{Y}$

$\mathrm{a}=$ Konstanta

$\mathrm{e}=$ Epsilon atau variabel pengganggu

Dalam penelitian ini, nilai-nilai dalam persamaan diatas dicari dengan menggunakan program SPSS.

\subsubsection{Pengujian Hipotesis}

\section{a. Uji Statistik t (Uji Parsial)}

Pengujian hipotesis yang dilakukan untuk mengetahui ada tidaknya pengaruh CSR terhadap profitabilitas perusahaan adalah uji t (uji parsial). Langkah-langkah dalam pengujian hipotesis yang dilakukan adalah sebagai berikut:
a) Menyatakan hipotesis nol $\left(\mathrm{H}_{0}\right)$ dan hipotesis alternatif $\left(\mathrm{H}_{\mathrm{a}}\right)$
b) Menetapkan Tingkat Signifikansi $(\alpha)$
c) Uji statistik t (Uji Parsial)
d) Penarikan kesimpulan.

\section{b. Koefisien Determinasi $\left(\mathbf{R}^{2}\right)$}

Kriteria nilai koefisien determinasi (Sudjana, 2011:257) adalah sebagai berikut:
a. Jika nilai $\mathrm{Kd}=0$ berarti tidak ada pengaruh variabel $\mathrm{X}$ terhadap varibel Y.
b. Jika nilai $\mathrm{Kd}=1$ berarti variasi (naik turunnya) variabel dependen $\mathrm{Y}$ adalah $100 \%$ dipengaruhi oleh variabel independen (variabel X).
c. Jika nilai $\mathrm{Kd}$ berada antara 0 sampai $1(0 \leq \mathrm{Kd} \leq 1)$ maka besarnya pengaruh variabel independen adalah sesuai dengan nilai $\mathrm{Kd}$ itu sendiri dan selebihnya berasal dari faktor-faktor yang lain.




\section{HASIL PENELITIAN DAN PEMBAHASAN}

\section{Deskripsi Variabel Penelitian}

\section{a. Pengungkapan Corporate Social Responsibility (CSR)}

Berikut adalah tabel jumlah pengungkapan Corporate Social Responsibility (CSR) serta indeks pengungkapan CSR (CSDI) pada perusahaan pertambangan yang menjadi sampel dalam penelitian ini.

Tabel 4.1

Indeks Pengungkapan CSR Perusahaan Pertambangan Periode 20112013

\begin{tabular}{|c|c|c|c|c|c|c|c|c|}
\hline \multirow[t]{2}{*}{ No. } & \multirow{2}{*}{$\begin{array}{c}\text { Nama } \\
\text { Perusahaan }\end{array}$} & \multirow{2}{*}{$\begin{array}{c}\text { Kode } \\
\text { Perusahaan }\end{array}$} & \multicolumn{3}{|c|}{$\begin{array}{c}\text { Jumlah Pengungkapan } \\
\text { CSR }\end{array}$} & \multicolumn{3}{|c|}{ CSDI } \\
\hline & & & 2011 & 2012 & 2013 & 2011 & 2012 & 2013 \\
\hline 1 & $\begin{array}{l}\text { PT Adaro } \\
\text { Energy Tbk }\end{array}$ & ADRO & 29 & 34 & 39 & 0,367 & 0,430 & 0,493 \\
\hline 2 & $\begin{array}{l}\text { PT Aneka } \\
\text { Tambang Tbk }\end{array}$ & ANTM & 36 & 42 & 46 & 0,455 & 0,531 & 0,582 \\
\hline 3 & $\begin{array}{l}\text { PT ATPK } \\
\text { Resources Tbk }\end{array}$ & ATPK & 16 & 17 & 19 & 0,202 & 0,215 & 0,240 \\
\hline 4 & $\begin{array}{l}\text { PT Benakat } \\
\text { Petrolium } \\
\text { Energy Tbk }\end{array}$ & BIPI & 30 & 32 & 46 & 0,379 & 0,405 & 0,582 \\
\hline 5 & $\begin{array}{l}\text { PT Berau Coal } \\
\text { Energy Tbk }\end{array}$ & BRAU & 38 & 31 & 39 & 0,481 & 0,392 & 0,493 \\
\hline 6 & $\begin{array}{l}\text { PT Bumi } \\
\text { Resources } \\
\text { Minerals Tbk }\end{array}$ & BUMI & 19 & 22 & 23 & 0,240 & 0,278 & 0,291 \\
\hline 7 & $\begin{array}{l}\text { PT Bayan } \\
\text { Resources Tbk }\end{array}$ & BYAN & 19 & 24 & 26 & 0,240 & 0,303 & 0,329 \\
\hline 8 & $\begin{array}{l}\text { PT Cita } \\
\text { Mineral } \\
\text { Investindo } \\
\text { Tbk }\end{array}$ & CITA & 11 & 13 & 17 & 0,139 & 0,164 & 0,215 \\
\hline 9 & $\begin{array}{l}\text { PT Citatah } \\
\text { Tbk }\end{array}$ & СТTH & 12 & 14 & 19 & 0,152 & 0,177 & 0,240 \\
\hline 10 & $\begin{array}{l}\text { PT Darma } \\
\text { Henwa Tbk }\end{array}$ & DEWA & 34 & 37 & 39 & 0,430 & 0,468 & 0,493 \\
\hline 11 & $\begin{array}{l}\text { PT Central } \\
\text { Omega } \\
\text { Resources Tbk }\end{array}$ & DKFT & 22 & 26 & 28 & 0,278 & 0,329 & 0,354 \\
\hline 12 & PT Elnusa Tbk & ELSA & 33 & 46 & 50 & 0,417 & 0,582 & 0,633 \\
\hline 13 & $\begin{array}{l}\text { PT Energi } \\
\text { Megah }\end{array}$ & ENRG & 26 & 28 & 48 & 0,329 & 0,354 & 0,607 \\
\hline
\end{tabular}




\begin{tabular}{|c|l|c|c|c|c|c|c|c|} 
& Persada Tbk & & & & & & & \\
\hline 14 & $\begin{array}{l}\text { PT Garda } \\
\text { Tujuh Buana } \\
\text { Tbk }\end{array}$ & GTBO & 13 & 19 & 22 & 0,164 & 0,240 & 0,278 \\
\hline 15 & $\begin{array}{l}\text { PT Resource } \\
\text { Alam } \\
\text { Indonesia Tbk }\end{array}$ & ITMG & 38 & 40 & 49 & 0,481 & 0,506 & 0,620 \\
\hline 16 & $\begin{array}{l}\text { PT Indo } \\
\text { Tambangraya } \\
\text { Megah Tbk }\end{array}$ & KKGI & 15 & 22 & 28 & 0,189 & 0,278 & 0,354 \\
\hline 17 & $\begin{array}{l}\text { PT Medco } \\
\text { Energi } \\
\text { Internasional } \\
\text { Tbk }\end{array}$ & MEDC & 26 & 25 & 29 & 0,329 & 0,316 & 0,367 \\
\hline 18 & $\begin{array}{l}\text { PT Mitra } \\
\text { Investindo } \\
\text { Tbk }\end{array}$ & MITI & 25 & 27 & 30 & 0,316 & 0,341 & 0,379 \\
\hline 19 & $\begin{array}{l}\text { PT Petrosea } \\
\text { Tbk }\end{array}$ & PTRO & 37 & 41 & 43 & 0,468 & 0,518 & 0,544 \\
\hline 20 & $\begin{array}{l}\text { PT Timah } \\
\text { (Persero) Tbk }\end{array}$ & TINS & 26 & 40 & 45 & 0,329 & 0,506 & 0,569 \\
\hline
\end{tabular}

Sumber: Olah data peneliti

Nilai rata-rata Pengungkapan Corporate Social Responsibiliy (CSR) perusahaan pertambangan yang terdaftar di Bursa Efek Indonesia selama tahun 2011-2013 adalah sebesar 37,34\% dari seluruh item yang mungkin di ungkapkan. Jumlah tersebut menunjukkan bahwa perusahaan pertambangan yang terdaftar di Bursa Efek Indonesia tidak banyak melakukan kegiatan CSR nya selama periode 2011-2013. Hal ini dikarenakan perusahaan pertambangan rata-rata melakukan kegiatan CSR nya hanya kurang dari setengah kegiatan CSR yang mungkin dapat dilakukan oleh perusahaan.

\section{b. Profitabilitas Perusahaan Pertambangan}

\section{1) Net Profit Margin (NPM)}

Berdasarkan table 4.2Perusahaan pertambangan yang terdaftar di Bursa Efek Indonesia selama tahun 2011-2013 rata-rata memperoleh NPM sebesar 9,45\%. Dari angka tersebut terlihat bahwa rata-rata peolehan NPM perusahaan pertambangan hanya kurang dari 10\%. Ini merupakan angka yang cukup kecil, yang mungkin disebabkan oleh keadaan ekonomi yang sedang tidak baik selama periode 2011-2013. Hal ini juga dibenarkan 
dengan beberapa perusahaan pertambangan yang mengalami kerugian, sehingga NPM perusahaan tersebut nilainya negatif.

Tabel 4.2

Net Profit Margin Perusahaan Pertambangan Periode 2011-2013

\begin{tabular}{|c|c|c|c|c|c|}
\hline \multirow{2}{*}{ No. } & \multirow{2}{*}{ Nama Perusahaan } & \multirow{2}{*}{$\begin{array}{c}\text { Kode } \\
\text { Perusahaan }\end{array}$} & \multicolumn{3}{|c|}{ Net Profit Margin } \\
\hline & & & 2011 & 2012 & 2013 \\
\hline 1 & PT Adaro Energy Tbk & ADRO & 0,1384 & 0,1029 & 0,0697 \\
\hline 2 & PT Aneka Tambang Tbk & ANTM & 0,1863 & 0,2864 & 0,0362 \\
\hline 3 & PT ATPK Resources Tbk & ATPK & $-0,1834$ & $-0,0922$ & 0,0518 \\
\hline 4 & $\begin{array}{l}\text { PT Benakat Petrolium } \\
\text { Energy Tbk }\end{array}$ & BIPI & $-0,1803$ & 0,0242 & 0,2902 \\
\hline 5 & PT Berau Coal Energy Tbk & BRAU & 0,0972 & $-0,1172$ & $-0,1137$ \\
\hline 6 & $\begin{array}{l}\text { PT Bumi Resources } \\
\text { Minerals Tbk }\end{array}$ & BUMI & 0,1450 & 0,2315 & 0,2756 \\
\hline 7 & PT Bayan Resources Tbk & BYAN & 0,1383 & 0,0386 & $-0,0481$ \\
\hline 8 & $\begin{array}{l}\text { PT Cita Mineral Investindo } \\
\text { Tbk }\end{array}$ & CITA & 0,0909 & 0,0905 & 0,1664 \\
\hline 9 & PT Citatah Tbk & СTTH & 0,0061 & 0,0170 & 0,0020 \\
\hline 10 & PT Darma Henwa Tbk & DEWA & $-0,0847$ & $-0,1236$ & $-0,2330$ \\
\hline 11 & $\begin{array}{l}\text { PT Central Omega } \\
\text { Resources Tbk }\end{array}$ & DKFT & 0,3155 & 0,3576 & 0,3996 \\
\hline 12 & PT Elnusa Tbk & ELSA & $-0,0063$ & 0,0283 & 0,0590 \\
\hline 13 & $\begin{array}{l}\text { PT Energi Megah Persada } \\
\text { Tbk }\end{array}$ & ENRG & 0,0819 & 0,1233 & 0,2109 \\
\hline 14 & PT Garda Tujuh Buana Tbk & GTBO & 0,2525 & 0,5048 & $-0,2113$ \\
\hline 15 & $\begin{array}{l}\text { PT Resource Alam } \\
\text { Indonesia Tbk }\end{array}$ & ITMG & 0,2292 & 0,1771 & 0,1057 \\
\hline 16 & $\begin{array}{l}\text { PT Indo Tambangraya } \\
\text { Megah Tbk }\end{array}$ & KKGI & 0,2117 & 0,1197 & 0,0891 \\
\hline 17 & $\begin{array}{l}\text { PT Medco Energi } \\
\text { Internasional Tbk }\end{array}$ & MEDC & 0,1111 & 0,0639 & 0,0141 \\
\hline 18 & PT Mitra Investindo Tbk & MITI & 0,1971 & 0,1464 & 0,1571 \\
\hline 19 & PT Petrosea Tbk & PTRO & 0,1995 & 0,1274 & 0,0480 \\
\hline 20 & PT Timah (Persero) Tbk & TINS & 0,1003 & 0,0586 & 0,0880 \\
\hline
\end{tabular}

Sumber: Olah data peneliti 


\section{2) Return On Asset (ROA)}

Berdasarkan table 4.3 Perusahaan pertambangan yang terdaftar di Bursa Efek Indonesia selama tahun 2011-2013 rata-rata memperoleh ROA sebesar 7,03\%. Angka ini cukup menggambarkan nilai ROA yang baik tetapi hal ini dibantu oleh beberapa perusahaan yang memperoleh ROA sangat tinggi. Secara umum angka ROA perusahaan cenderung mengalami penurunan pada tahun 2012 dan 2013 dibandinkan tahun sebelumnya.

Tabel 4.3

Return On Asset Perusahaan Pertambangan Periode 2011-2013

\begin{tabular}{|c|c|c|c|c|c|}
\hline \multirow{2}{*}{ No. } & \multirow{2}{*}{ Nama Perusahaan } & \multirow{2}{*}{$\begin{array}{c}\text { Kode } \\
\text { Perusahaan }\end{array}$} & \multicolumn{3}{|c|}{ Return On asset } \\
\hline & & & 2011 & 2012 & 2013 \\
\hline 1 & PT Adaro Energy Tbk & ADRO & 0,0975 & 0,0572 & 0,0340 \\
\hline 2 & PT Aneka Tambang Tbk & ANTM & 0,1268 & 0,1518 & 0,0187 \\
\hline 3 & PT ATPK Resources Tbk & ATPK & $-0,2225$ & $-0,1109$ & 0,0087 \\
\hline 4 & $\begin{array}{l}\text { PT Benakat Petrolium } \\
\text { Energy Tbk }\end{array}$ & BIPI & $-0,0164$ & 0,0019 & 0,0412 \\
\hline 5 & PT Berau Coal Energy Tbk & BRAU & 0,0668 & $-0,0835$ & $-0,0810$ \\
\hline 6 & $\begin{array}{l}\text { PT Bumi Resources } \\
\text { Minerals Tbk }\end{array}$ & BUMI & 0,0015 & 0,0042 & 0,0040 \\
\hline 7 & PT Bayan Resources Tbk & BYAN & 0,1273 & 0,0287 & $-0,0352$ \\
\hline 8 & $\begin{array}{l}\text { PT Cita Mineral Investindo } \\
\text { Tbk }\end{array}$ & CITA & 0,1488 & 0,1200 & 0,1819 \\
\hline 9 & PT Citatah Tbk & CTTH & 0,0041 & 0,0105 & 0,0014 \\
\hline 10 & PT Darma Henwa Tbk & DEWA & $-0,0591$ & $-0,0942$ & $-0,1414$ \\
\hline 11 & $\begin{array}{l}\text { PT Central Omega } \\
\text { Resources Tbk }\end{array}$ & DKFT & 0,1363 & 0,1976 & 0,2154 \\
\hline 12 & PT Elnusa Tbk & ELSA & $-0,0068$ & 0,0315 & 0,0555 \\
\hline 13 & $\begin{array}{l}\text { PT Energi Megah Persada } \\
\text { Tbk }\end{array}$ & ENRG & 0,0100 & 0,0073 & 0,0734 \\
\hline 14 & PT Garda Tujuh Buana Tbk & GTBO & 0,1590 & 0,2536 & $-0,0673$ \\
\hline 15 & $\begin{array}{l}\text { PT Resource Alam } \\
\text { Indonesia Tbk }\end{array}$ & ITMG & 0,3459 & 0,2897 & 0,1655 \\
\hline 16 & $\begin{array}{l}\text { PT Indo Tambangraya } \\
\text { Megah Tbk }\end{array}$ & KKGI & 0,4662 & 0,2272 & 0,1625 \\
\hline 17 & $\begin{array}{l}\text { PT Medco Energi } \\
\text { Internasional Tbk }\end{array}$ & MEDC & 0,0350 & 0,0047 & 0,0049 \\
\hline 18 & PT Mitra Investindo Tbk & MITI & 0,2329 & 0,1487 & 0,1401 \\
\hline 19 & PT Petrosea Tbk & PTRO & 0,1395 & 0,0927 & 0,0339 \\
\hline 20 & PT Timah (Persero) Tbk & TINS & 0,1365 & 0,0704 & 0,0653 \\
\hline
\end{tabular}

Sumber: Olah data peneliti 


\subsubsection{Hasil Analisis Data}

a. Uji Asumsi Klasik

1) Uji Normalitas

- Uji Normalitas Untuk Variabel CSR Dan NPM

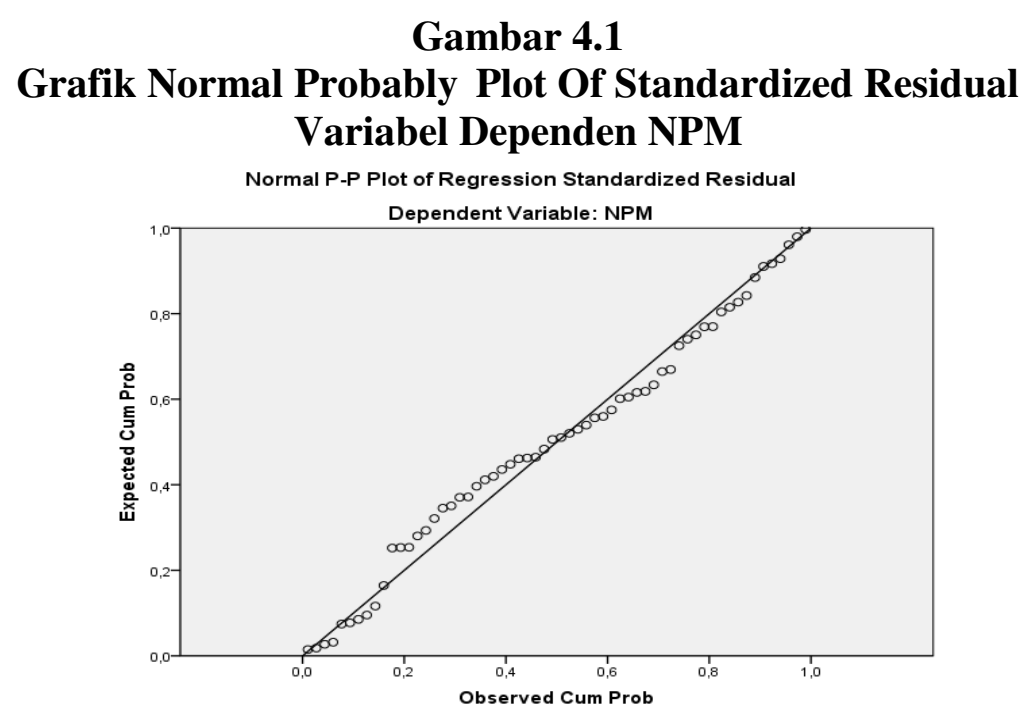

Sumber: Olah data peneliti di SPSS 19

Berdasarkan hasil uji normalitas dengan metode grafik yang dilakukan untuk variabel NPM sebagai variabel dependen pada gambar diatas, maka model regresi memenuhi asumsi normalitas. Dapat terlihat bahwa data menyebar hanya di sekitar garis diagonal dan mengikuti arah garis diagonal tersebut. 
- Uji Normalitas Untuk Variabel CSR Dan ROA

\section{Gambar 4.2}

\section{Grafik Normal Probably Plot Of Standardized Residual} Variabel Dependen ROA

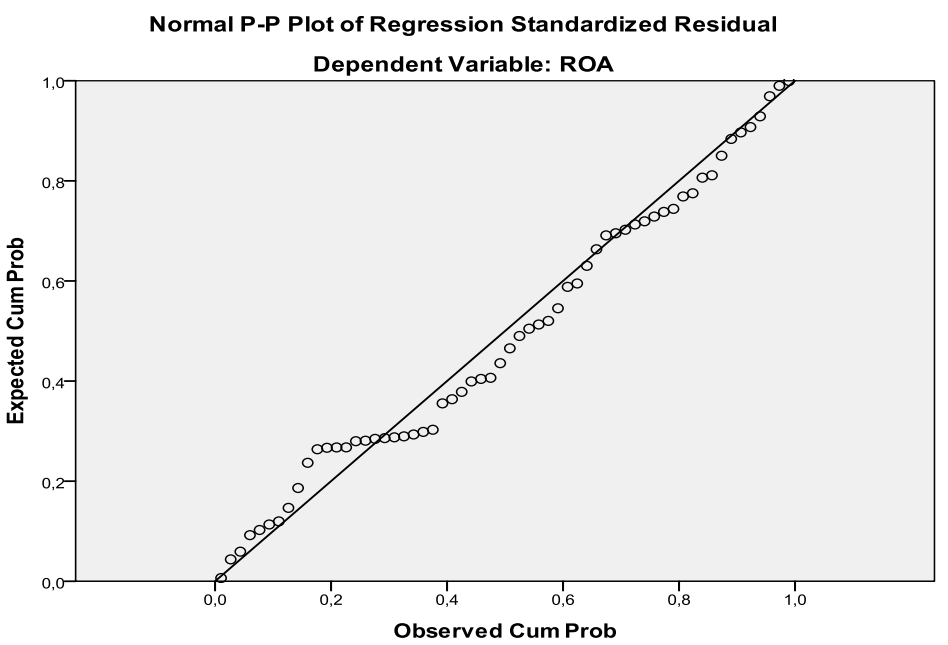

Sumber: Olah data peneliti di SPSS 19

Berdasarkan hasil uji normalitas dengan metode grafik yang dilakukan untuk variabel ROA sebagai variabel dependen pada gambar diatas, maka model regresi memenuhi asumsi normalitas. Dapat terlihat bahwa data menyebar hanya di sekitar garis diagonal dan mengikuti arah garis diagonal tersebut.

Selain dengan melihat grafik normal probably plot of standardized residual diatas, uji normalitas dalam penelitian ini dilakukan dengan uji One Sample Kolmogorov-Smirnov Test. Berikut hasil pengujian normalitas untuk variabel CSDI, NPM, serta ROA. 
Tabel 4.4

Hasil Uji Normalitas Metode Statistik One-Sample Kolmogorov-Smirnov Test

\begin{tabular}{|c|c|c|c|c|}
\hline & CSDI & NPM & $\mathrm{ROA}$ \\
\hline \multicolumn{2}{|l|}{$\mathrm{N}$} & 60 & 60 & 60 \\
\hline Norn & Mean & ,3734177 & ,0945110 & ,0703593 \\
\hline Parameters ${ }^{a, b}$ & Std. Deviation & 13413430 & 14698827 & 11985903, \\
\hline Most & Absc & 079 & 081 & 099 \\
\hline Differences & Posit & 079 & ,062 & 099 \\
\hline & Negative &,- 077 &,- 081 &,- 099 \\
\hline Kolmog & & 615 & 7629 & ,770 \\
\hline Asymp. Sic & & ,844 & ,823 &, 593 \\
\hline
\end{tabular}

Sumber: Olah data peneliti pada SPSS 19

Dengan melihat hasil uji normalitas pada tabel diatas, nilai asymp. Sig. (2-tailed) untuk variabel CSDI adalah 0,844 dimana 0,844>0,05, sehingga dapat dinyatakan bahwa data berdistribusi normal. Untuk variabel NPM adalah 0,823 dimana 0,823 >0,05, sehingga dapat dinyatakan bahwa data berdistribusi normal. Serta untuk variabel ROA adalah 0,593 dimana 0,593 $>0,05$, sehingga dapat dinyatakan bahwa data berdistribusi normal.

Berdasarkan hasil uji normalitas metode grafik dan metode statistik yang telah di uraikan diatas, maka dapat disimpulkan bahwa data dalam penelitian ini berdistribusi normal.

\section{2) Uji Autokorelasi}

Berikut adalah tabel untuk hasil uji Durbin-Watson:

\section{Tabel 4.5}

Hasil Uji Durbin Watson Model Summary

\begin{tabular}{|l|c|r|r|r|r|}
\hline Model & $\mathrm{R}$ & $\mathrm{R}$ Square & $\begin{array}{c}\text { Adjusted R } \\
\text { Square }\end{array}$ & $\begin{array}{c}\text { Std. Error of the } \\
\text { Estimate }\end{array}$ & $\begin{array}{c}\text { Durbin- } \\
\text { Watson }\end{array}$ \\
\hline NPM &, $053^{\mathrm{a}}$ &, 003 &,- 014 &, 15263395 & 2,377 \\
ROA &, $051^{\mathrm{a}}$ &, 003 &,- 015 &, 12072989 & 1,638 \\
\hline
\end{tabular}

Sumber: Olah data peneliti pada SPSS 19

Berdasarkan tabel diatas, nilai DW untuk variabel dependen NPM adalah 2,377 serta untuk variabel dependen ROA adalah 1,638. Selanjutnya nilai ini dibandingkan dengan nilai DW tabel DW. Dengan jumlah sampel penelitian (n) 60 dan jumlah variabel independen $(K=1)$ maka diperoleh nilai $\mathrm{du}=1,6162 \mathrm{dan} \mathrm{dl}=1,5485$ pada tabel DW. Dengan demikian untuk variabel dependen NPM nilai du $<$ dw $<4$-du $(1,6162<$ 
$2,377<2,3838)$, sehinga dapat disimpulkan bahwa tidak terdapat autokorelasi baik positif maupun negatif. Demikian pula untuk uji DW pada variabel dependen ROA du $<$ DW $<4$-du $(1,61162<1,638<2,3838)$ maka dapat disimpulkan tidak ada autokorelasi baik positif maupun negatif. dengan demikian model regresi linier sederhana layak pada penelitian ini karena data pada penelitian ini bebas dari masalah auto korelasi.

\section{3) Uji Heteroskedastisitas}

- Hasil Uji Heteroskedastisitas Untuk Variabel Dependen NPM

\section{Gambar 4.3}

\section{Hasil Uji Heteroskedastisitas Variabel CSR Dan NPM}

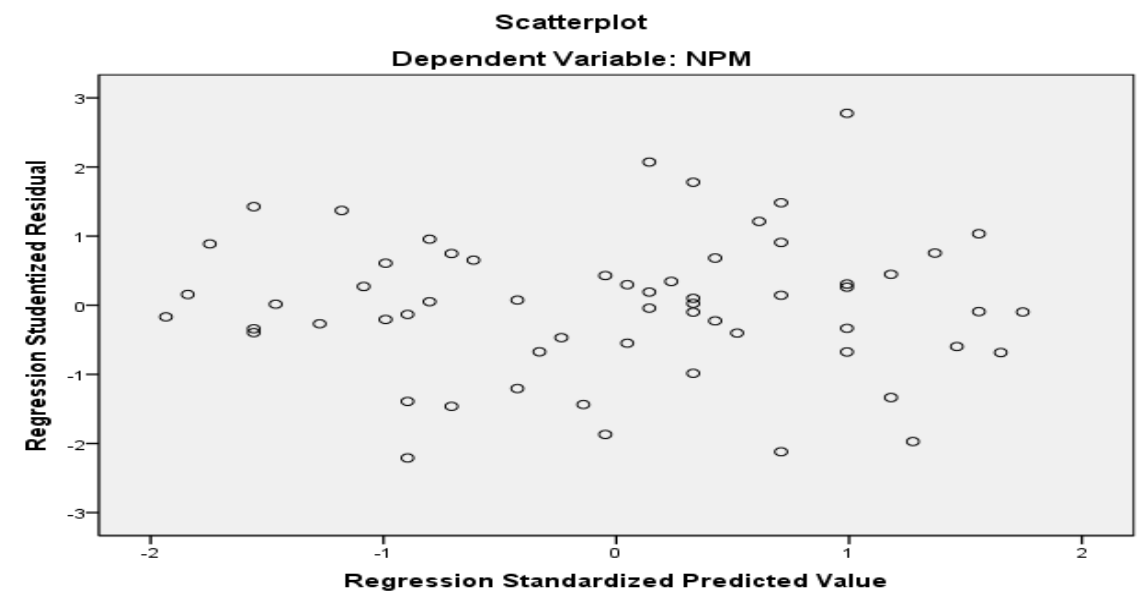

Sumber: Olah data peneliti di SPSS 19

Dengan melihat tampilan grafik scatterplot untuk variabel CSR dan NPM pada gambar di atas terlihat bahwa titik-titik menyebar secara acak, tidak membentuk sebuah pola tertentu yang jelas. Titik-titik tersebut juga tersebar baik diatas maupun dibawah angka 0 pada sumbu Y. Hal ini mengindikasikan bahwa tidak terjadi heterokedastisitas dalam regresi linier sederhana ini, sehingga model regresi layak dipakai dalam penelitian ini. 
- Hasil Uji Heteroskedastisitas Untuk Variabel Dependen ROA

Gambar 4.4

Hasil Uji Heteroskedastisitas Variabel CSR Dan ROA



Sumber: Olah data peneliti di SPSS 19

Dengan melihat tampilan grafik scatterplot untuk variabel CSR dan ROA pada gambar di atas terlihat bahwa titik-titik menyebar secara acak, tidak membentuk sebuah pola tertentu yang jelas. Titik-titik tersebut juga tersebar baik diatas maupun dibawah angka 0 pada sumbu Y. Hal ini mengindikasikan bahwa tidak terjadi gejala heterokedastisitas dalam regresi linier sederhana ini, sehingga model regresi layak dipakai dalam penelitian ini.

\section{b. Analisis Regresi Linier Sederhana}

1) Pengaruh CSR Terhadap NPM

Pembuatan persamaan regresi linier sederhana untuk pengaruh CSR terhadap NPM dapat dilakukan dengan mengintepretasikan angka-angka yang termuat dalam tabel dibawah ini. 
Tabel 4.6

Persamaan Regresi Linier sederhana Variabel Dependen NPM

Coefficients $^{\mathrm{a}}$

\begin{tabular}{|l|r|r|r|r|r|}
\hline \multirow{2}{*}{ Model } & \multicolumn{2}{|c|}{$\begin{array}{c}\text { Unstandardized } \\
\text { Coefficients }\end{array}$} & $\begin{array}{c}\text { Standardized } \\
\text { Coefficients }\end{array}$ & \multicolumn{1}{c|}{$\mathrm{T}$} & \multicolumn{1}{c|}{ Sig. } \\
\cline { 2 - 7 } & \multicolumn{1}{|c|}{ B } & Std. Error & Beta & &, 056 \\
\hline $1 \quad$ (Constant) &, 111 &, 057 & & 1,949 &, 758 \\
\hline
\end{tabular}

Sumber: Olah data peneliti pada SPSS 19

Hubungan antara CSR Sebagai variabel independen (X) dan NPM sebagai variabel dependen (Y) dapat dirumuskan kedalam persamaan berikut:

$$
\mathrm{Y}=0,111-0,044 \mathrm{X}
$$

2) Pengaruh CSR Terhadap ROA

Pembuatan persamaan regresi linier sederhana untuk pengaruh CSR terhadap ROA dapat dilakukan dengan mengintepretasikan angka-angka yang termuat dalam tabel dibawah ini.

.Tabel 4.7

Persamaan Regresi Linier Sederhana Variabel Dependen ROA

Coefficients $^{\mathrm{a}}$



Sumber: Olah data peneliti pada SPSS 19

Hubungan antara CSR Sebagai variabel independen (X) dan ROA sebagai variabel dependen (Y) dapat dirumuskan kedalam persamaan berikut:

$$
\mathrm{Y}=0,087-0,046 \mathrm{X}
$$




\section{c. Pengujian Hipotesis}

1) Uji Statistik t

Uji $\mathrm{t}$ dilakukan untuk menguji hipotesis apakah satu variabel independen secara individual yaitu indeks pengungkapan tanggungjawab sosial perusahaan (CSDI) memiliki pengaruh terhadap variabel dependen, yaitu Net Profit Margin (NPM) dan Return On Asset (ROA). Berikut hasil uji statistik t dalam penelitian ini:

\section{Tabel 4.8}

\section{Hasil Uji Statistik t}

\begin{tabular}{|c|c|c|c|c|c|}
\hline \multirow{2}{*}{ Variabel } & \multicolumn{2}{|c|}{$\begin{array}{l}\text { Unstandardized } \\
\text { Coefficients }\end{array}$} & $\begin{array}{c}\text { Standardized } \\
\text { Coefficients }\end{array}$ & \multirow{2}{*}{$\mathrm{T}$} & \multirow{2}{*}{ Sig. } \\
\hline & $\mathrm{B}$ & Std. Error & Beta & & \\
\hline CSR terhadap NPM &,- 044 & , 144 &,- 041 &,- 309 & ,758 \\
\hline CSR terhadap ROA &,- 046 & ,117 &,- 051 &,- 390 & ,698 \\
\hline
\end{tabular}

Sumber: Olah data peneliti pada SPSS 19

a. Pengaruh Pengungkapan CSR Terhadap NPM

Berdasarkan hasil untuk uji statistik t pada tabel 4.8 diatas diperoleh nilai t-hitung sebesar $-0,309$. Selanjutnya nilai t-hitung ini dibandingkan dengan nilai t-tabel untuk mengetahui apakah hipotesis 1 diterima. Untuk nilai t-tabel $(\mathrm{df}=58, \alpha=0,05)$ df merupakan hasil dari n-k-1 ( $\mathrm{n}=$ responden, $\mathrm{k}=$ variabel independen) adalah sebesar 2,001. Oleh karena penelitian ini uji 2 arah maka titik kritis penerimaan $\mathrm{H} 0$ berada antara -2,001 sampai 2,001.

Dengan demikian karena nilai -t hitung > nilai -t table dimana -0,309 $>-2,001$, variabel CSR dinyatakan tidak berpengaruh tehadap NPM. Maka untuk hipotesis pertama (H1) ditolak dan $\mathrm{H} 0$ diterima.

\section{b. Pengaruh Pengungkapan CSR Terhadap ROA}

Berdasarkan hasil untuk uji statistik t pada tabel 4.8 diatas diperoleh nilai t-hitung sebesar $-0,390$. Selanjutnya nilai t-hitung ini dibandingkan dengan nilai t-tabel untuk mengetahui apakah hipotesis 1 diterima. Untuk nilai t-tabel $(\mathrm{df}=58, \alpha=0,05)$ df merupakan hasil dari n-k-1 $(\mathrm{n}=$ responden, $\mathrm{k}=$ variabel independen) adalah sebesar 2,001. Oleh karena penelitian ini uji 2 arah maka titik kritis penerimaan $\mathrm{H} 0$ berada antara -2,001 sampai dengan 2,001.

Dengan demikian karena nilai -t hitung > nilai - $t$ table dimana $-0,390$ $>-2,001$, variabel CSR dinyatakan tidak berpengaruh tehadap ROA. Maka untuk hipotesis kedua (H2) ditolak dan $\mathrm{H} 0$ diterima. 


\section{2) Koefisien Determinasi}

\section{Tabel 4.9}

\section{Hasil Koefisien Determinasi}

\begin{tabular}{|c|c|c|c|c|}
\hline \multicolumn{1}{|c|}{ Model Summary $^{\mathbf{b}}$} \\
\hline Variabel & $\mathrm{R}$ & $\mathrm{R}$ Square & $\begin{array}{c}\text { Adjusted R } \\
\text { Square }\end{array}$ & $\begin{array}{c}\text { Std. Error of the } \\
\text { Estimate }\end{array}$ \\
\hline CSR Terhadap NPM &, $041^{\mathrm{a}}$ &, 002 &,- 016 &, 14812816 \\
CSR Terhadap ROA &, $051^{\mathrm{a}}$ &, 003 &,- 015 &, 12072989 \\
& & & & \\
\hline
\end{tabular}

Sumber: Olah data peneliti pada SPSS 19

\section{a. Kemampuan CSR Mempengaruhi NPM}

Berdasarkan tabel di atas, nilai $\mathrm{r}^{2}$ untuk pengaruh variabel CSR terhadap NPM adalah sebesar 0,002 atau hanya $0,2 \%$. Angka tersebut menunjukkan bahwa variabel pengungkapan CSR tergolong tidak mampu dalam mempengaruhi NPM karena nilai $r^{2}$ nya mendekati angka 0 . CSR hanya mempengaruhi NPM sebesar 0,2\%. Sementara sisanya sebesar 99,8 $\%$ NPM dipengaruhi oleh variabel lain seperti perputaran modal kerja, aspek pendapatan, rasio likuiditas, ukuran perusahaan, dan berbagi faktor lain yang mampu mempengaruhi NPM.

b. Kemampuan CSR Mempengaruhi ROA

Berdasarkan tabel 4.9 diatas, nilai koefisien determinasi $\left(r^{2}\right)$ untuk pengaruh variabel CSR terhadap ROA adalah sebesar 0,003 atau hanya 0,3\%. Angka tersebut menunjukkan bahwa variabel pengungkapan CSR tergolong tidak mampu dalam mempengaruhi ROA karena nilai $r^{2}$ nya mendekati angka 0. CSR hanya mempengaruhi ROA sebesar 0,3\%. Sementara sisanya sebesar 99,7 \% NPM dipengaruhi oleh variabel lain seperti perputaran modal kerja, aspek pendapatan, rasio likuiditas, ukuran perusahaan, dan berbagi faktor lain yang mampu mempengaruhi NPM.

\subsection{Pembahasan}

\subsubsection{Pengaruh Pengungkapan CSR Terhadap NPM}

Dalam pengujian hipotesis untuk uji statistik t diperoleh nilai t hitung sebesar -0,309. Oleh karena nilai $-\mathrm{t}$ hitung > -t tabel dimana -0,309 > 0,2001 maka hipotesis pertama (H1) ditolak dan H0 diterima. Berarti Corporate Social Responsibility (CSR) tidak berpengaruh terhadap profitabilitas yang diwakilkan oleh Net Profit Margin (NPM). 


\subsubsection{Pengaruh Pengungkapan CSR Terhadap ROA}

Dalam pengujian hipotesis untuk uji statistik $t$ diperoleh nilai t hitung sebesar -0,390. Oleh karena nilai $-t$ hitung $>$-t tabel dimana $-0,390>-$ 0,2001 maka hipotesis pertama (H2) ditolak dan H0 diterima. Berarti Corporate Social Responsibility (CSR) tidak berpengaruh terhadap profitabilitas yang diwakilkan oleh Return On Asset (ROA). Untuk koefisien determinasi diperoleh nilai koefisien determinasi sebesar 0,003. Dimana nilai ini mendekati angka 0 sehingga CSR dinyatakan tidak mempengaruhi profitabilitas yang diwakilkan oleh ROA.

\section{KESIMPULAN}

\subsection{Kesimpulan}

Berdasrakan hasil penelitian dan pembahasan yang telah diuraikan sebelumnya, maka dapat ditarik kesimpulan sebagai berikut:

1. Berdasarkan hasil uji statistik $\mathrm{t}$ menunjukkan bahwa Corporate Social Responsibility (CSR) tidak berpengaruh terhadap profitabilitas perusahaan pertambangan. Baik yang diwakilkan oleh Net Profit Margin (NPM) maupun yang diwakilkan oleh Return On Asset (ROA)

2. Hasil pengujian koefisien determinasi yang dilakukan, nilai $\mathrm{r}^{2}$ untuk pengaruh CSR terhadap NPM adalah sebesar 0,02 yang berarti mendekati angka 0 . Hal ini menunjukkan bahwa CSR tidak dapat mempengaruhi Profitabilitas yang diwakilkan oleh NPM. Demikian pula nilai $\mathrm{r}^{2}$ untuk pengaruh CSR terhadap ROA adalah sebesar 0,03 yang berarti mendekati angka 0. Hal ini menunjukkan bahwa CSR tidak dapat mempengaruhi Profitabilitas yang diwakilkan oleh ROA.

\section{DAFTAR PUSTAKA}

Daniri, Mas Achmad, 2008. "Standarisasi Tanggung Jawab Sosial Perusahaan (Bag I)". www.madani-ri.com/2008/01/17/standarisasi-tanggungjawab-sosialperusahaan-bagi

Darsono dan Ashari, 2005. Pedoman Praktis Memahami Laporan Keuangan, Andi, Yogyakarta.

Darwin, Ali. 2008. CSR: Standards dan Reporting. Makalah Disampaikan pada Seminar Nasional CSR sebagai Kewajiban Asasi Perusahaan telaah Pemerintah, Pengusaha, dan Dewan Standar Akuntansi, Unika Soegijapranata, Semarang, 18 Juni.

Gendro, Andi. 2012. Beberapa Pengertian Citra Perusahaan (Corporate Image). 
Artikel Berita Nasional, (www.pramesnet.com).

Ghozali, 2005. Analisis Multivariate. Edisi Ketiga. Universitas Diponegoro

Gujarati, Damondar. 2003. Ekonometrika Dasar. Jakarta : Penerbit Erlangga.

Hanafi, M . M. dan Halim, A. 2004. Analisis Laporan Keuangan. Yogyakarta : UBP AMPYKPN

Harahap, Sofyan Syafri. 2007. Analisis Kritis atas Laporan Keuangan. Edisi Kesatu. PT. Raja Grafindo Persada. Jakarta

Hernitra, Wellarizma. 2011. Pengaruh Pengungkapan Corporate Social Responsibility (CSR) Terhadap Profitabilitas Perusahaan. Skripsi. Jurusan Akuntansi Fakultas Ekonomi Universitas Jember.

Horne, James C. Van dan Wachoicz John M. 2005. Prinsip-Prinsip Manajemen Keuangan. Jakarta: Salemba Empat

Indrawan, Danu Candra. 2011. Pengaruh Corporate Social Responsibility Terhadap Kinerja Perusahaan. Skripsi. Semarang: Fakultas Ekonomi Universitas Diponegoro.

Jefkins, Frank. 2004. Public Relations. Jakarta: Erlangga.

Mawarani, Elisabeth Inge. 2010. Pengaruh Pengungkapan Corporate Social Responsibility (Csr) Terhadap Profitabilitas Perusahaan Pertambangan Di Bursa Efek Indonesia. Disertasi Tidak Diterbitkan. Surabaya: Fakultas Ekonomi Universitas Pembangunan Nasional Veteran.

Munawir. 2001. Analisa Laporan Keuangan. Edisi kelima. Yogyakarta : Liberty Rahmatullah Dan Kurniati, Trianita. 2011. Panduan Praktis Pengelolaan CSR (Corporate Social Responsibility). Padeglang Dan Depok: Samudera Biru.

Sartono, Agus. 2001. Manajemen Keuangan Teori Dan Aplikasi. Yogyakarta: BPFE

Sawir, Agnes. 2000. Analisis Kinerja Keuangan dan Perencanaan Keuangan Perusahaan. Jakarta: PT Gramedia PustakaUtama

Sembiring, E.R. 2005. Karakteristik perusahaan dan pengungkapan tanggung jawab sosial: study empiris pada perusahaan yang tercatat di Bursa Efek Jakarta, Simposium Nasional Akuntansi VIII.

Simamora, Henry. 2006. Akuntansi Basis Utama Pengambilan Keputusan. Jakarta : SalembaEmpat

Sugiyono, 2003. Metode Penelitian Bisnis. Bandung: CV Alfabeta.

Utama, Sidharta, 2007. "Evaluasi Insfrastruktur Pendukung Pelaporan Tanggung Jawab Sosial dan Lingkungan di Indonesia," www.google.com.

‘www.idx.co.id 